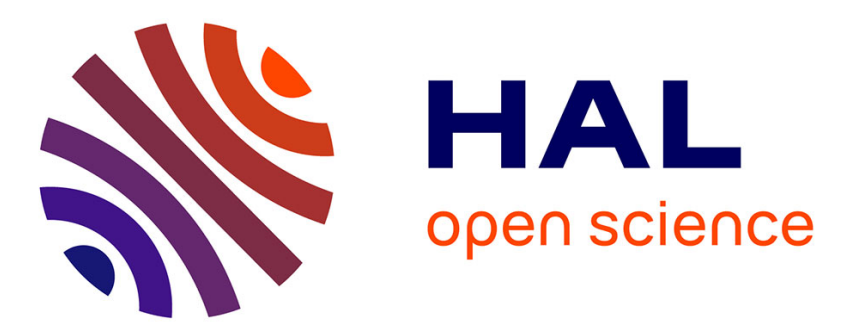

\title{
Assessment of the activity of RND-type multidrug efflux pumps in using tetraphenylphosphonium ions
}

Rimantas Daugelavičius, Andrius Buivydas, Ana Senčilo, Dennis H. Bamford

\section{To cite this version:}

Rimantas Daugelavičius, Andrius Buivydas, Ana Senčilo, Dennis H. Bamford. Assessment of the activity of RND-type multidrug efflux pumps in using tetraphenylphosphonium ions. International Journal of Antimicrobial Agents, 2010, 36 (3), pp.234. 10.1016/j.ijantimicag.2010.03.028 . hal00609001

\section{HAL Id: hal-00609001 \\ https://hal.science/hal-00609001}

Submitted on 17 Jul 2011

HAL is a multi-disciplinary open access archive for the deposit and dissemination of scientific research documents, whether they are published or not. The documents may come from teaching and research institutions in France or abroad, or from public or private research centers.
L'archive ouverte pluridisciplinaire HAL, est destinée au dépôt et à la diffusion de documents scientifiques de niveau recherche, publiés ou non, émanant des établissements d'enseignement et de recherche français ou étrangers, des laboratoires publics ou privés. 


\section{Accepted Manuscript}

Title: Assessment of the activity of RND-type multidrug efflux pumps in Pseudomonas aeruginosa using tetraphenylphosphonium ions

Authors: Rimantas Daugelavičius, Andrius Buivydas, Ana Senčilo, Dennis H. Bamford

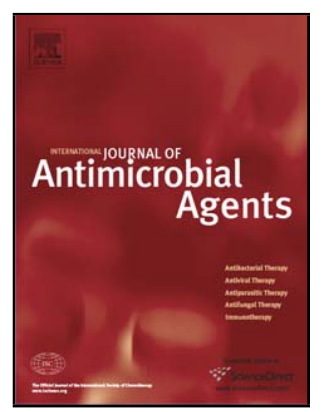

PII: S0924-8579(10)00162-7

DOI:

Reference: doi:10.1016/j.ijantimicag.2010.03.028

To appear in: International Journal of Antimicrobial Agents

Received date: $\quad$ 6-2-2010

Revised date: $\quad 23-3-2010$

Accepted date: $\quad 24-3-2010$

Please cite this article as: Daugelavičius R, Buivydas A, Senčilo A, Bamford DH, Assessment of the activity of RND-type multidrug efflux pumps in Pseudomonas aeruginosa using tetraphenylphosphonium ions, International Journal of Antimicrobial Agents (2008), doi:10.1016/j.ijantimicag.2010.03.028

This is a PDF file of an unedited manuscript that has been accepted for publication. As a service to our customers we are providing this early version of the manuscript. The manuscript will undergo copyediting, typesetting, and review of the resulting proof before it is published in its final form. Please note that during the production process errors may be discovered which could affect the content, and all legal disclaimers that apply to the journal pertain. 


\section{Assessment of the activity of RND-type multidrug efflux pumps in Pseudomonas aeruginosa using tetraphenylphosphonium ions}

Rimantas Daugelavičius ${ }^{a, b, 1, \star}$, Andrius Buivydas ${ }^{a, c, 1}$, Ana Senčilo ${ }^{a, c}$, Dennis H. Bamford ${ }^{c}$

a Department of Biochemistry and Biophysics, Vilnius University, Lithuania

${ }^{\mathrm{b}}$ Department of Biochemistry and Biotechnologies, Vytautas Magnus University, Kaunas, Lithuania

${ }^{c}$ Department of Biological Sciences and Institute of Biotechnology, University of Helsinki, Finland

ARTICLE INFO

Article history:

Received 6 February 2010

Accepted 24 March 2010

Keywords:

RND-type efflux pumps

Pseudomonas aeruginosa

Tetraphenylphosphonium

Outer membrane permeability

* Corresponding author. Present address: Department of Biochemistry and

Biotechnologies, Faculty of Natural Sciences, Vytautas Magnus University, Vileikos 8, LT44404 Kaunas, Lithuania. Tel.: +370 37327 917; fax: +370 37327916 . 
E-mail address: r.daugelavicius@gmf.vdu.It (R. Daugelavičius).

${ }^{1}$ These authors contributed equally to this work. 


\section{ABSTRACT}

Multidrug resistance (MDR) pumps are one of the major causes of antibiotic resistance in Pseudomonas aeruginosa. Thus, fast and reliable methods are needed to assay the efficiency of MDR pumps in these bacteria. In this study, it was demonstrated that a membrane voltage $(\Delta \psi)$ indicator tetraphenylphosphonium $\left(\mathrm{TPP}^{+}\right)$in combination with the efflux pump inhibitor phenylalanyl-arginyl- $\beta$-naphthylamide can be used to monitor the activity of resistance-nodulation-cell division (RND)-type efflux pumps in $P$. aeruginosa. By controlling the outer membrane permeability and $\Delta \psi$, electrochemical measurements of RND pump activity in real time were performed. It was demonstrated that the composition of the medium, the presence of nutrients and the level of aeration affect the efficiency of the TPP $^{+}$-extruding activity of $P$. aeruginosa, urging the standardisation of experimental conditions to obtain quantitative and comparative results. 


\section{Introduction}

Pseudomonas aeruginosa is an exceptionally versatile organism that can adapt to a wide range of ecological niches [1]. A major reason for its prominence as an opportunistic pathogen is its high intrinsic resistance to antimicrobials, including antibiotics and disinfectants. In addition to the low outer membrane (OM) permeability to lipophilic compounds and the highly active periplasmic $\beta$-lactamases, multiple efflux pumps are major causes of antibiotic resistance in $P$. aeruginosa [2]. It is of crucial importance to develop rapid methods to evaluate the activity of multidrug resistance (MDR) pumps and to estimate their efficiency in clinical isolates.

Several methods are used to study the activity of MDR pumps. The most popular methods are based on monitoring the accumulation of fluorescent probes, especially ethidium [3]. In addition, radiolabelled antibiotics [4], tetraphenylphosphonium ions $\left(\mathrm{TPP}^{+}\right)$[5] or other lipophilic compounds have been used such assays. However, these methods include procedures (pelleting or filtration of cells, incubation in closed vials) leading to conditions affecting the energy state of bacteria and, therefore, the functioning of the pumps.

Lipophilic cations such as $\mathrm{TPP}^{+}$are popular indicators of membrane voltage [transmembrane electrical potential difference $(\Delta \psi)]$ in bacteria. By measuring the interaction of TPP ${ }^{+}$with Gram-negative bacteria, it is also possible to detect changes in the permeability of the OM [6]. In 1986, Midgley [7] showed that the level of $\mathrm{TPP}^{+}$accumulation in bacteria depends on the efficiency of pumps extruding this indicator cation back to the incubation medium. Further studies revealed that lipophilic cations are the most universal substrates of MDR pumps in prokaryotic [5,8,9] and eukaryotic [10] cells. 
Here we describe an electrochemical assay for $\mathrm{TPP}^{+}$accumulation in $P$. aeruginosa cells using selective electrodes. Such monitoring of $\mathrm{TPP}^{+}$accumulation in the absence and presence of phenylalanyl-arginyl- $\beta$-naphthylamide $(\mathrm{PA} \beta \mathrm{N})$, a general inhibitor of resistance-nodulation-cell division (RND)-type pumps [11], allows real-time evaluation of the total activity of the RND-type MDR pumps in these bacteria. We demonstrate that the composition of the medium, the presence of nutrients and the level of aeration affect the efficiency of the MDR pump-based TPP ${ }^{+}$-extruding activity of $P$. aeruginosa, urging the standardisation of experimental conditions to obtain quantitative and comparative results.

\section{Materials and methods}

\subsection{Bacterial strains and chemicals}

Pseudomonas aeruginosa strain PAO1 was obtained from Prof. Patrick Plésiat (CHU Minjoz, Besançon, France). Gramicidin D (GD), polymyxin B (PMB) sulphate, polymyxin B nonapeptide (PMBN) hydrochloride, PA $\beta N$ and ethylene diamine tetra-acetic acid (EDTA) were from Sigma (St Louis, MO) and $\mathrm{TPP}^{+}$chloride was from Aldrich (Taufkirchen, Germany).

\subsection{Bacterial growth and minimum inhibitory concentration (MIC) determination conditions} Pseudomonas aeruginosa cells were cultivated in Luria-Bertani broth (LB) [12] containing diminished $\mathrm{NaCl}$ concentration (0.5\%). Cell growth was monitored by measuring the optical density at $550 \mathrm{~nm}\left(\mathrm{OD}_{550}\right)$ using a Selecta Clormic digital spectrophotometer (J.P. Selecta, 
Barcelona, Spain). MICs of $\mathrm{TPP}^{+}$and $\mathrm{PA} \beta \mathrm{N}$ were determined by the microdilution method as described by Wiegand et al. [13].

\subsection{Electrochemical measurements}

Experiments were performed in $10 \mathrm{~mL}$ or $50 \mathrm{~mL}$ thermostated vessels at $37^{\circ} \mathrm{C}$ with magnetic stirring. Cell cultures were grown to an appropriate $O D_{550}$ and were transferred directly to the vessels or collected by centrifugation for $15 \mathrm{~min}$ at $7000 \mathrm{rpm}$ at $4{ }^{\circ} \mathrm{C}$ (Sorvall SLA-1500 rotor; Thermo Fisher Scientific Inc., Waltham, MA). Pelleted cells were resuspended in $100 \mathrm{mM}$ sodium phosphate $(\mathrm{pH} 8.0)$ to a density of $1-2 \times 10^{11}$ colony-forming units $/ \mathrm{mL}$ and kept on ice until used (maximum $4 \mathrm{~h}$ ).

Measurements of $\mathrm{TPP}^{+}$concentration were performed simultaneously in four reaction vessels as described previously $[6,14]$. A representative set of curves from three independent measurements is presented.

\section{Results}

\subsection{Media conditions affecting the multidrug resistance pump activities in Pseudomonas} aeruginosa

Possible reasons for the limited $\mathrm{TPP}^{+}$accumulation in Gram-negative bacteria are: (i) low $\Delta \psi$; (ii) low permeability of the OM; and (iii) high activity of MDR pumps. Both the OM and the pumps prevent $\mathrm{TPP}^{+}$accumulation. Therefore, when assessing pump activity it is crucial to establish conditions warranting high and stable permeability of the OM to TPP ${ }^{+}$ without affecting the $\Delta \psi$ and the activity of MDR pumps. 
EDTA treatment is used [6] to increase OM permeability to lipophilic compounds and to rapidly equilibrate $\mathrm{TPP}^{+}$across the cell envelope of Gram-negative bacteria. Addition of 0.4 mM EDTA to $P$. aeruginosa suspension in $100 \mathrm{mM}$ Tris buffer induced complete release of the cell accumulated $\mathrm{TPP}^{+}$(Fig. 1a, red curve). It induced only a transient accumulation of $\mathrm{TPP}^{+}$in $50 \mathrm{mM}$ Tris buffer (Fig.1a, black curve). Leakage of the accumulated TPP ${ }^{+}$to the medium and the drop in the suspension turbidity (Fig. 1a, insert) indicated that EDTA rapidly lysed the cells.

Consequently, as EDTA treatment cannot be applied to $P$. aeruginosa cells in Tris buffer, different phosphate buffer concentrations were used for the following experiments (Fig. 1b). At all concentrations studied, except $400 \mathrm{mM}$, EDTA induced an additional accumulation of $\mathrm{TPP}^{+}$, whereas the universal inhibitor of RND-type MDR pumps PABN induced a strong release of the accumulated TPP ${ }^{+}$(Fig. 1b). Parallel measurements indicated that EDTA induced a moderate decrease of the cell suspension $\mathrm{OD}_{550}$ only when $50 \mathrm{mM}$ phosphate was used. Addition of PA $\beta N$ had no effect on the culture turbidity (Fig 1b, insert). The channel-forming antibiotic GD induced an additional leakage of TPP ${ }^{+}$, but the suspension $\mathrm{OD}_{550}$ considerably decreased only after the addition of PMB (Fig. 1b, insert). Control measurements showed that low OM permeability increasing concentrations of PMB added after PABN did not induce any additional accumulation of $\mathrm{TPP}^{+}$(not shown, but see Fig. 3). Overall, these data indicate that depolarisation of the plasma membrane (PM) is the principal reason for the PA $\beta N$-induced release of $\mathrm{TPP}^{+}$. We note that these results are valid only with $P$. aeruginosa and in phosphate buffer without nutrients. Viability measurements revealed that the MIC for $\mathrm{TPP}^{+}$is $>8192 \mu \mathrm{g} / \mathrm{mL}$, whereas the combination of $\mathrm{TPP}^{+}$with 
PA $\beta N$ decreased it to $512 \mu \mathrm{g} / \mathrm{mL}$, both of these values being considerably higher than the 3 $\mu \mathrm{M}(1.12 \mu \mathrm{g} / \mathrm{mL})$ concentration used for assay of the pump activities.

If $\mathrm{TPP}^{+}$is a substrate and PA $\beta N$ is an inhibitor of RND-type pumps, blockage of pump activity should increase the accumulation of TPP ${ }^{+}$. Bacterial MDR pumps are usually activated by nutrients such as glucose $[11,15]$. However, $\operatorname{TPP}^{+}$accumulation in $P$. aeruginosa was not sensitive to glucose (not shown). In LB medium the cells did not accumulate significant amounts of TPP ${ }^{+}$(Fig. 1c, blue and red curves). However, when PA $\beta N$ was added, a strong accumulation of TPP ${ }^{+}$occurred indicating the suppression of $\mathrm{TPP}^{+}$-extruding pump activities. GD had a weak effect on the distribution of $\mathrm{TPP}^{+}$between the cells and the LB medium, but subsequent additions of PMB released most of the cellassociated indicator cations, indicating that accumulation of $\mathrm{TPP}^{+}$was a $\Delta \psi$-dependent process.

The difference in the initial accumulation of TPP ${ }^{+}$by the cells in phosphate buffer and LB medium suggests that LB components have a considerable effect on the efficiency of MDR pumps and/or OM permeability to TPP ${ }^{+}$. The $\Delta \psi$ and, consequently, the accumulation of $\mathrm{TPP}^{+}$are medium $\mathrm{pH}$-dependent characteristics of the bacteria (compare Fig. 1b, lilac and red curves; Fig. 1c, blue and red curves). In such a situation, the low buffering capacity of LB complicates the studies of MDR pumps using charged indicator substrates. To increase the buffer capacity, LB was diluted with $400 \mathrm{mM}$ sodium phosphate (1:1). Initial accumulation of TPP ${ }^{+}$in the buffered LB (Fig. 1c, black curve) proceeded considerably more slowly compared with the measurements in $200 \mathrm{mM}$ phosphate buffer (Fig. 1b, blue curve) or in unbuffered LB medium (Fig. 1c, red curve). A low amplitude of EDTA-induced accumulation of $\mathrm{TPP}^{+}$was common in all the cases when fresh LB-containing medium was 
used (see below). Attempts to permeabilise the OM using another popular permeabiliser, PMBN, were unsuccessful. In addition, PMB was less active when added after PMBN (not shown). Despite the low efficiency of the OM permeabilisers, PA $\beta N$ induced a considerable accumulation of TPP ${ }^{+}$. The following addition of GD had a weak effect, but the subsequent additions of PMB caused an effective release of accumulated TPP ${ }^{+}$. Experiments with heatinactivated cells (Fig. 1c, green curve) indicated that the sharp initial effect of PA $\beta N$ on the potential of the TPP ${ }^{+}$-selective electrode has no connection with the activity of MDR pumps.

$\mathrm{PA} \beta \mathrm{N}$-induced $\mathrm{TPP}^{+}$accumulation can be the result of either inhibition of efflux pumps or permeabilisation of the $\mathrm{OM}$, or both. To acquire more information on the mechanism of PA $\beta N$ action on the capacity of cells to accumulate $\mathrm{TPP}^{+}$, gradually increasing concentrations of the inhibitor were used (Fig. 2). In phosphate buffer starting at the lowest concentrations tested, PABN only released cell-accumulated TPP ${ }^{+}$(Fig. 2a,c). In phosphate buffer-diluted LB, PAßN-induced changes in the accumulation of $\mathrm{TPP}^{+}$had a more complex nature dependent on the presence or absence of EDTA. In the presence of EDTA, low ( $>7.5 \mu \mathrm{g} / \mathrm{mL}$ ) concentrations of PABN induced an additional accumulation of $\operatorname{TPP}^{+}$(Fig. $2 b$ ). The second phase of the inhibitor-induced TPP ${ }^{+}$accumulation was observed at $30 \mu \mathrm{g} / \mathrm{mL}$ and higher concentrations of PA $\beta N$. At very high concentrations of PABN $(>120 \mu \mathrm{g} / \mathrm{mL})$ the additional accumulation of TPP ${ }^{+}$was followed by its release. In the absence of EDTA, PA $\beta N$ was ineffective up to $30 \mu \mathrm{g} / \mathrm{mL}$, but the concentration increase induced additional accumulation of $\mathrm{TPP}^{+}$(Fig. 2d). However, EDTA addition after PABN induced further TPP ${ }^{+}$ accumulation. This indicates that PA $\beta N$ is not an effective permeabiliser of the $O M$. Consequently, the ratio of the cell-accumulated amounts of $\mathrm{TPP}^{+}$after and before addition 
of PABN can be considered as a measure of the total activity of PABN-sensitive MDR pumps.

\subsection{Impact of aeration on the efficiency of multidrug resistance pumps}

Another experimental factor, frequently varied during studies on MDR pumps, is the aeration of the sample. To assess the role of aeration, experiments were performed in large vessels containing $30 \mathrm{~mL}$ of bacterial suspension. The level of aeration was varied by changing the intensity of magnetic stirring [14]. In the case of the cells grown to an $\mathrm{OD}_{550}$ of 1, pelleted and transferred to fresh LB medium, accumulation of $\mathrm{TPP}^{+}$was only transient (Fig. 3a). Further addition of EDTA only slightly increased the accumulation. Addition of $\mathrm{PA} \beta \mathrm{N}$ induced strong but reversible accumulation of $\mathrm{TPP}^{+}$. The extent of reversibility increased with the increase in aeration. PMB at low concentrations induced additional accumulation of TPP ${ }^{+}$, indicating low OM permeability. Such PMB-induced TPP ${ }^{+}$ accumulation was observed even in the presence of 2 mM EDTA (not shown).

The depolarising efficiency of PMB was also related to the intensity of aeration; $10 \mu \mathrm{g} / \mathrm{mL}$ PMB was enough to induce PM depolarisation at conditions of the highest aeration, but ca. $80 \mu \mathrm{g} / \mathrm{mL}$ was needed at the lowest aeration level. Noteworthy, further increase in the PMB concentration did not lead to faster depolarisation of the PM. Subsequent addition of GD depolarised the PM at all aeration levels studied (Fig. 3a).

Direct cell samples from exponentially growing culture were less sensitive to the level of aeration (Fig. 3b vs. Fig. 3a); $10 \mu \mathrm{g} / \mathrm{mL}$ PMB initiated depolarisation of the PM only at the 
lowest aeration level (Fig. 3b). This suggests that at conditions of very weak aeration, the EDTA-disrupted barrier of the OM was not restored.

When the same experiment was performed with overnight grown and pelleted cells, only weak dependences of $\mathrm{TPP}^{+}$accumulation and the sensitivity of the cells to PMB on aeration were observed. At these conditions, EDTA was not able to induce any accumulation of $\mathrm{TPP}^{+}$(Fig. 3a vs. Fig. 3c). However, the cells were even less sensitive to differences in aeration levels when direct overnight culture samples were utilised (Fig. 3d). In this case, at all aeration levels PA $\beta N$ caused a stable $\mathrm{TPP}^{+}$accumulation and low concentrations of PMB did not induce an additional one, indicating that EDTA was able to increased OM permeability to the maximum level.

Based on these results, it appears that the aeration level and the sampling method are important in respect to the efflux pumps' activity measurements. These results also indicate that the change of medium composition can be the main reason for the culture growth phase-related changes of MDR pump activities.

\section{Discussion}

Here we present results of efflux studies in liquid $P$. aeruginosa cultures where a popular $\Delta \psi$ indicator and a universal substrate of MDR pumps $\left(\mathrm{TPP}^{+}\right)$in combination with a pump inhibitor $(\mathrm{PA} \beta \mathrm{N})$ are used for electrochemical real-time monitoring of total RND-type efflux pump activity. During the recording, the cell suspension was aerated and thermostated, reagents were added to the reaction mixture and samples were taken for additional analyses without interrupting the experiment or changing the culture conditions. 
We discovered that in phosphate buffer, PA $\beta N$ causes depolarisation of the PM (Fig. 1b). This depolarising effect of $\mathrm{PA} \beta \mathrm{N}$ can be prevented by supplementing the buffer with nutrients of the LB medium (Fig. 1c) with the consequence of additional $\mathrm{TPP}^{+}$accumulation. It has been shown [11] that the inhibitory action of PA $\beta N$ is not caused by dissipation of $\Delta \psi$ but depends on direct interaction with the efflux system. This depolarisation can be due to a very intensive $\Delta \psi$-exhausting extrusion of PA $\beta N$ from the cells or to the inhibitor-induced short-circuiting of the PM. It should be mentioned that at very high concentrations PA $\beta N$ induces TPP ${ }^{+}$leakage also in the presence of LB (see Fig. 2b,d).

Results obtained in the presence of LB underline the importance of the nutrient-induced intensification of metabolism on the mode of action of MDR pumps. It is possible that the high level of proton-motive force is not enough to keep the $\mathrm{H}^{+}$flux-driven MDR pumps active and it is necessary to guarantee high concentration of protons (low local $\mathrm{pH}$ ) in the near vicinity of the drug-extruding pumps. This factor could also explain the need for glucose for activation of MDR pumps in enterobacteria [11,15].

This description of the variables affecting $P$. aeruginosa efflux systems emphasises the need to set up accredited standard conditions for efflux pump assays. Experiments indicate that the medium composition and the aeration level are critical parameters affecting accumulation of $\mathrm{TPP}^{+}$in $P$. aeruginosa cells. Additional $\mathrm{TPP}^{+}$accumulation following addition of PA $\beta N$ is highest at conditions not enabling the reconstruction of the EDTAdisturbed $\mathrm{OM}$ barrier, i.e. at low levels of aeration and/or in the exhausted growth medium (Fig. 3). In parallel to repair of the OM barrier, at optimal growth condition cells can respond to inhibition of the main RND-type pumps by activating alternative ones. The impact of 
aeration diminishes when overnight cultures are used. Consequently, buffered stationaryphase cell cultures are the most appropriate for comparative studies of multiple samples, e.g. clinical isolates of $P$. aeruginosa.

\section{Acknowledgments}

The authors would like to acknowledge the technical assistance provided by the Bamford Laboratory personnel (University of Helsinki, Finland). They are grateful to Patrick Plésiat and Didier Hocquet for providing $P$. aeruginosa strains.

\section{Funding}

This work was supported by the Finnish Center of Excellence in Virus Research Program (2006-2011) of the Academy of Finland (grant 1129684 to DHB), the Lithuanian State Science and Studies Foundation (grant C-01/2009 to RD) and COST action BM0701 (ATENS).

\section{Competing interests}

None declared.

\section{Ethical approval}

Not required. 


\section{References}

[1] Wiehlmann L, Wagner G, Cramer N, Siebert B, Gudowius P, Morales G, et al. Population structure of Pseudomonas aeruginosa. Proc Natl Acad Sci USA 2007; $104: 8101-6$.

[2] Poole K. Efflux-mediated antimicrobial resistance. J Antimicrob Chemother 2005;56:2051.

[3] Babayan A, Nikaido H. In Pseudomonas aeruginosa ethidium bromide does not induce its own degradation or the assembly of pumps involved in its efflux. Biochem Biophys Res Commun 2004;324:1065-8.

[4] Aires JR, Nikaido H. Aminoglycosides are captured from both periplasm and cytoplasm by the AcrD multidrug efflux transporter of Escherichia coli. J Bacteriol 2005;187:19239.

[5] Rotem D, Schuldiner S. EmrE, a multidrug transporter from Escherichia coli, transports monovalent and divalent substrates with the same stoichiometry. J Biol Chem 2004;279:48787-93.

[6] Daugelavicius R, Cvirkaite V, Gaidelyte A, Bakiene E, Gabrenaite-Verkhovskaya R, Bamford DH. Penetration of enveloped double-stranded RNA bacteriophages phi13 and phi6 into Pseudomonas syringae cells. J Virol 2005;79:5017-26.

[7] Midgley M. The phosphonium ion efflux system of Escherichia coli: relationship to the ethidium efflux system and energetic studies. J Gen Microbiol 1986;132:3187-93.

[8] Li XZ, Nikaido H. Efflux-mediated drug resistance in bacteria. Drugs 2004;64:159-204.

[9] Nishioka T, Ogawa W, Kuroda T, Katsu T, Tsuchiya T. Gene cloning and characterization of EfmA, a multidrug efflux pump, from Enterococcus faecium. Biol Pharm Bull 2009;32:483-8. 
[10] Gros P, Talbot F, Tang-Wai D, Bibi E, Kaback HR. Lipophilic cations: a group of model substrates for the multidrug-resistance transporter. Biochemistry 1992;31:19928.

[11] Lomovskaya O, Warren MS, Lee A, Galazzo J, Fronko R, Lee M, et al. Identification and characterization of inhibitors of multidrug resistance efflux pumps in Pseudomonas aeruginosa: novel agents for combination therapy. Antimicrob Agents Chemother $2001 ; 45: 105-16$.

[12] Sambrook J, Russell DW. Molecular cloning: a laboratory manual. Cold Spring Harbor, NY: Cold Spring Harbor Laboratory Press; 2001.

[13] Wiegand I, Hilpert K, Hancock RE. Agar and broth dilution methods to determine the minimal inhibitory concentration (MIC) of antimicrobial substances. Nat Protoc 2008;3:163-75.

[14] Daugelavicius R, Gaidelyte A, Cvirkaite-Krupovic V, Bamford DH. On-line monitoring of changes in host cell physiology during the one-step growth cycle of Bacillus phage Bam35. J Microbiol Methods 2007;69:174-9.

[15] Pannek S, Higgins PG, Steinke P, Jonas D, Akova M, Bohnert JA, et al. Multidrug efflux inhibition in Acinetobacter baumannii: comparison between 1-(1-naphthylmethyl)piperazine and phenyl-arginine- $\beta$-naphthylamide. J Antimicrob Chemother 2006;57:9704. 
Fig. 1. Influence of media composition on efflux pump activity towards tetraphenylphosphonium ions $\left(\mathrm{TPP}^{+}\right)$. Experiments were performed in $5 \mathrm{~mL}$ of $\mathrm{Tris} / \mathrm{HCl}(\mathrm{a})$, sodium phosphate (b) or Luria-Bertani (LB) or LB diluted 1:1 with $400 \mathrm{mM}$ sodium phosphate (NaP) (c) as indicated in the figure. Media $\mathrm{pH}$ was 8.0 unless otherwise indicated. A concentrated cell suspension was added to the vessels to obtain an optical density at $550 \mathrm{~nm}\left(\mathrm{OD}_{550}\right)$ of 1 . Ethylene diamine tetra-acetic acid (EDTA) was added to a final concentration of $0.4 \mathrm{mM}$, and phenylalanyl-arginyl- $\beta$-naphthylamide $(\mathrm{PA} \beta \mathrm{N})$, gramicidin D (GD) and polymyxin B (PMB) were added to concentrations of $60 \mu \mathrm{g} / \mathrm{mL}, 4 \mu \mathrm{g} / \mathrm{mL}$ and 60 $\mu \mathrm{g} / \mathrm{mL}$, respectively. In (a) and (b), $70 \mu \mathrm{L}$ samples were taken from the vessels for turbidity measurements throughout the experiments (inserts). In (c, green curve), cells were inactivated by incubating the concentrated suspension at $70^{\circ} \mathrm{C}$ for $15 \mathrm{~min}$.

Fig. 2. Influence of phenylalanyl-arginyl- $\beta$-naphthylamide $(P A \beta N)$ concentration and media composition on the capacity of Pseudomonas aeruginosa cells to accumulate tetraphenylphosphonium $\left(\mathrm{TPP}^{+}\right)$. Experiments were performed in $5 \mathrm{~mL}$ of sodium phosphate $(\mathrm{a}, \mathrm{c})$ or Luria-Bertani (LB) diluted 1:1 with $400 \mathrm{mM}$ sodium phosphate $(\mathrm{b}, \mathrm{d})$. A concentrated cell suspension was added to the vessels to obtain an optical density at 550 $\mathrm{nm}\left(\mathrm{OD}_{550}\right)$ of 1 . Ethylene diamine tetra-acetic acid (EDTA) was added to a final concentration of $0.4 \mathrm{mM}$, and gramicidin $\mathrm{D}(\mathrm{GD})$ and polymyxin $\mathrm{B}(\mathrm{PMB})$ were added to concentrations of $4 \mu \mathrm{g} / \mathrm{mL}$ and $60 \mu \mathrm{g} / \mathrm{mL}$, respectively. PA $\beta \mathrm{N}$ was added to the concentrations indicated in the figure $(\mu \mathrm{g} / \mathrm{mL})$. In (a) and (b) EDTA was added before PA $\beta N$, whereas in (c) and (d) EDTA was added after addition of PA $\beta N$.

Fig. 3. Dependence of tetraphenylphosphonium $\left(\mathrm{TPP}^{+}\right)$accumulation on the aeration level of Pseudomonas aeruginosa cell cultures. Cells were grown to an optical density at $550 \mathrm{~nm}$ 
$\left(O D_{550}\right)$ of $1(a, b)$ or overnight $(c, d)$. In $(b)$ and $(d)$ measurements were performed by diluting cultures 1:1 with $400 \mathrm{mM}$ sodium phosphate ( $\mathrm{pH} 8.0)$, and in (a) and (c) by adding concentrated cell suspension to buffered Luria-Bertani (LB) medium to $\mathrm{OD}_{550}$ values of 0.5 and 1 , respectively. The intensity of aeration was controlled by magnetic stirring using four levels: 'high' (green curves, ++++); 'intermediate' (blue, +++); 'low' (red, ++); and 'very low' (black, + ). TPP ${ }^{+}$, ethylene diamine tetra-acetic acid (EDTA), phenylalanyl-arginyl- $\beta$ naphthylamide (PA $\beta N)$ and gramicidin $D(G D)$ were added to the cell suspensions to final concentrations of $3 \mu \mathrm{M}, 0.4 \mathrm{mM}, 60 \mu \mathrm{g} / \mathrm{mL}$ and $4 \mu \mathrm{g} / \mathrm{mL}$, respectively. Polymyxin B (PMB) was added to the concentrations indicated in the figure $(\mu \mathrm{g} / \mathrm{mL})$. 
(a)

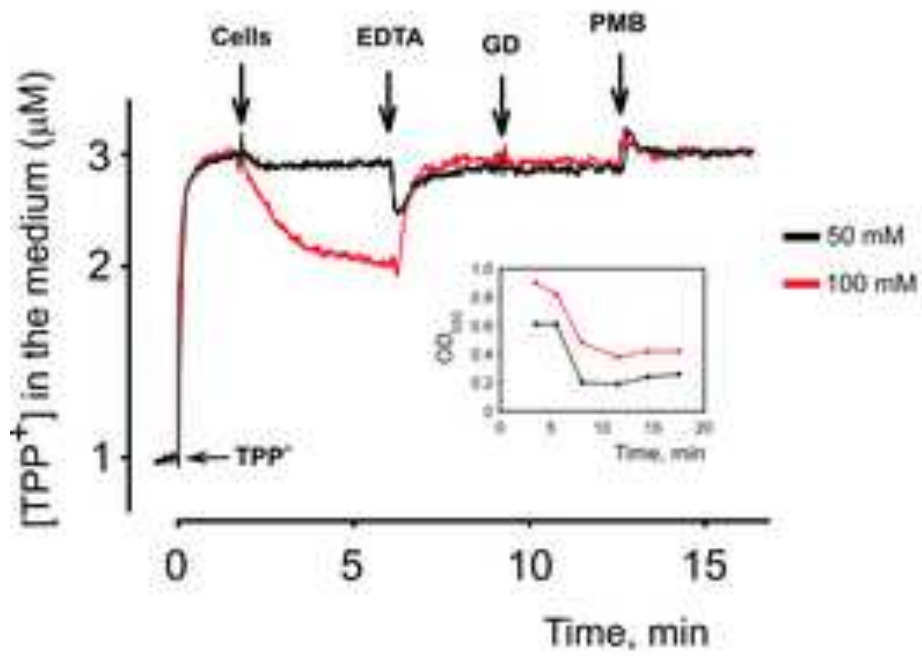

(b)
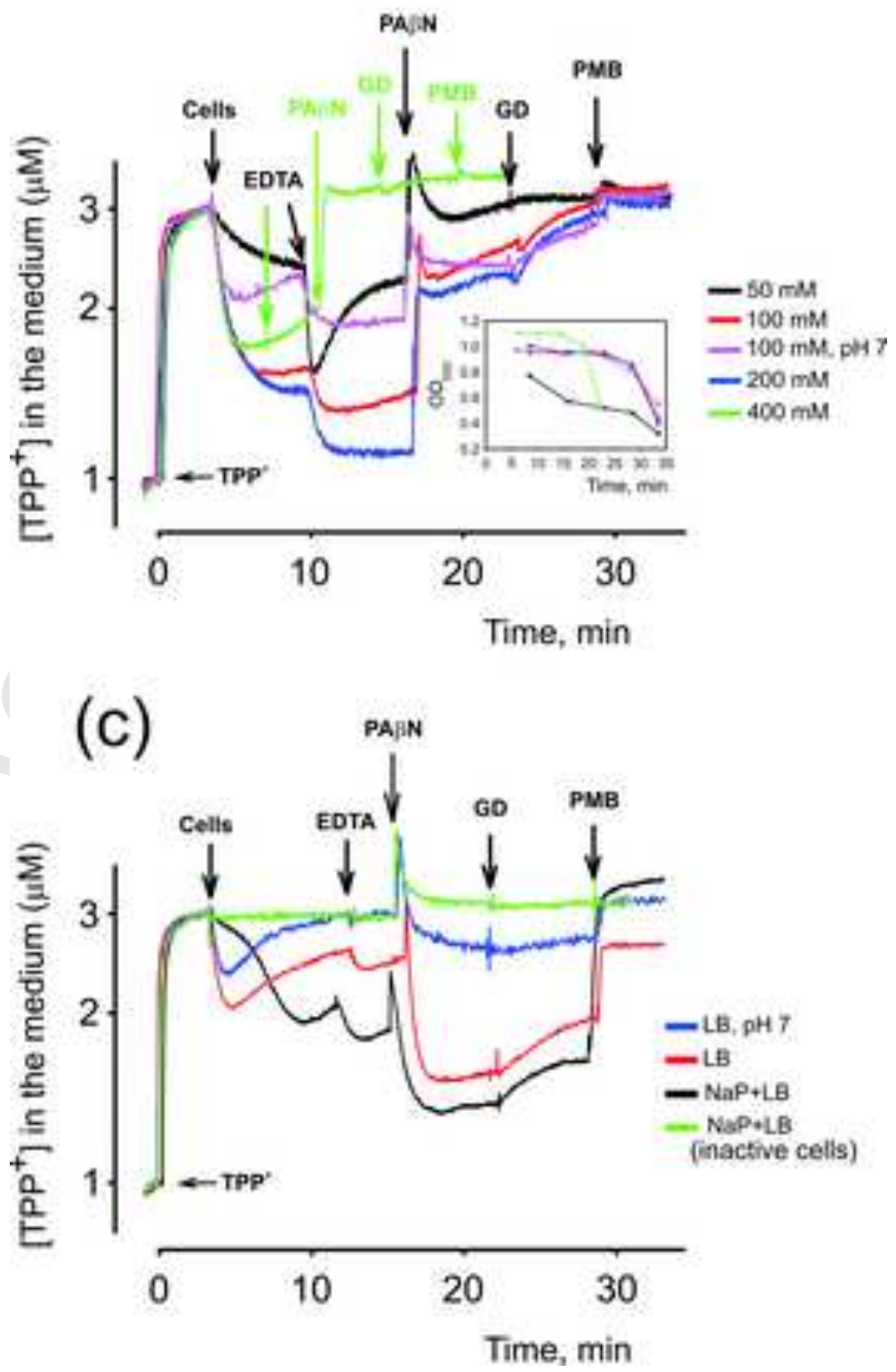
(a)
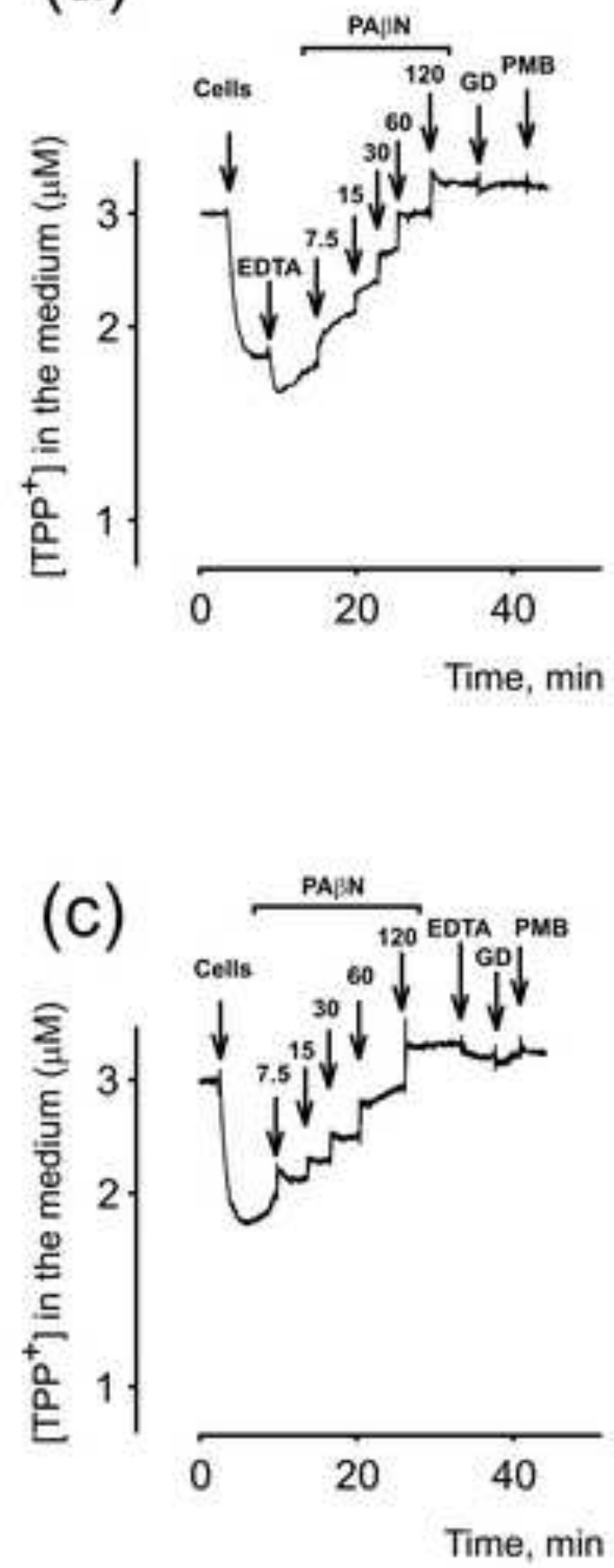

(b)
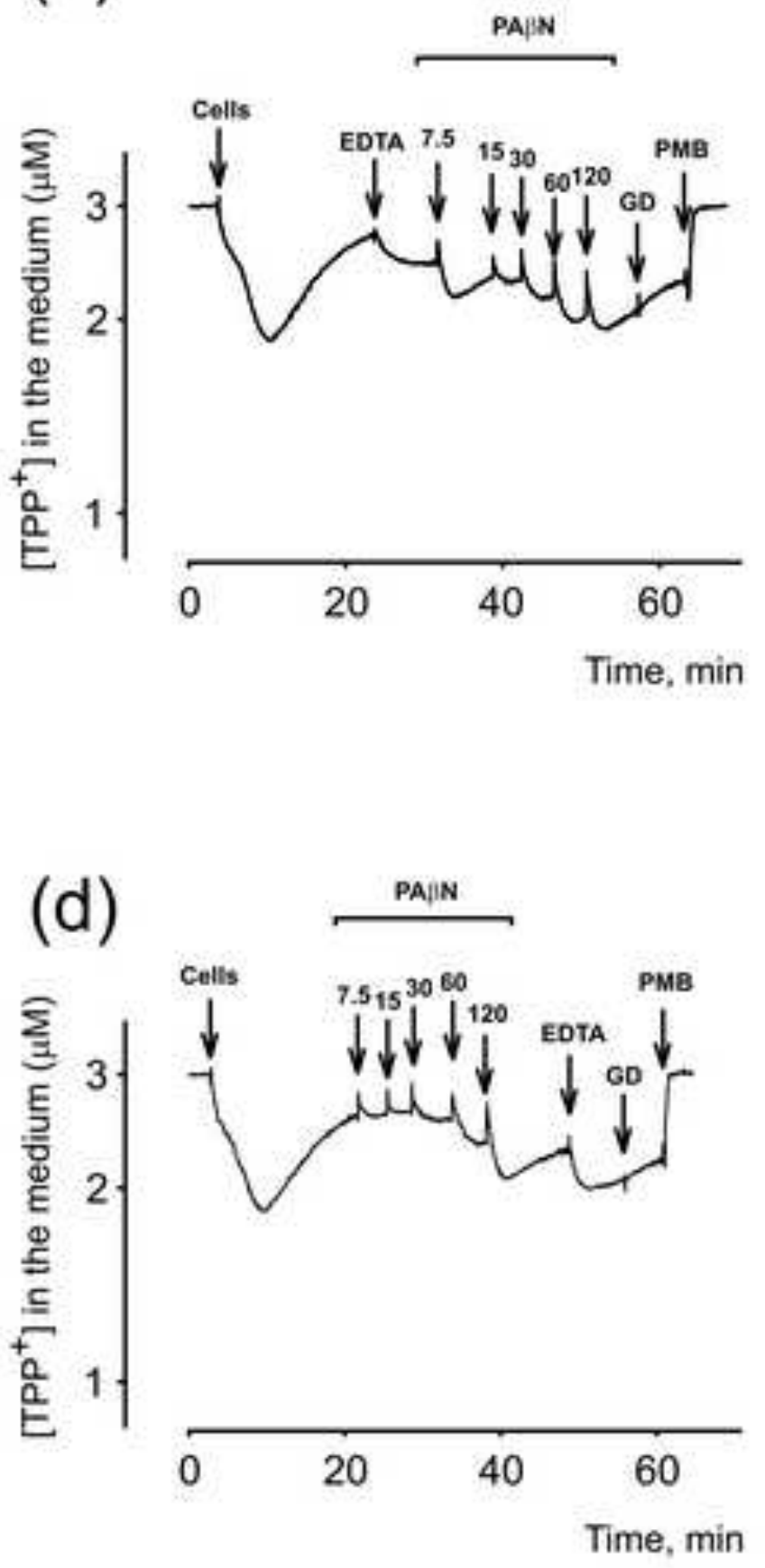

rage $1 y$ or $2 U$ 
(a)

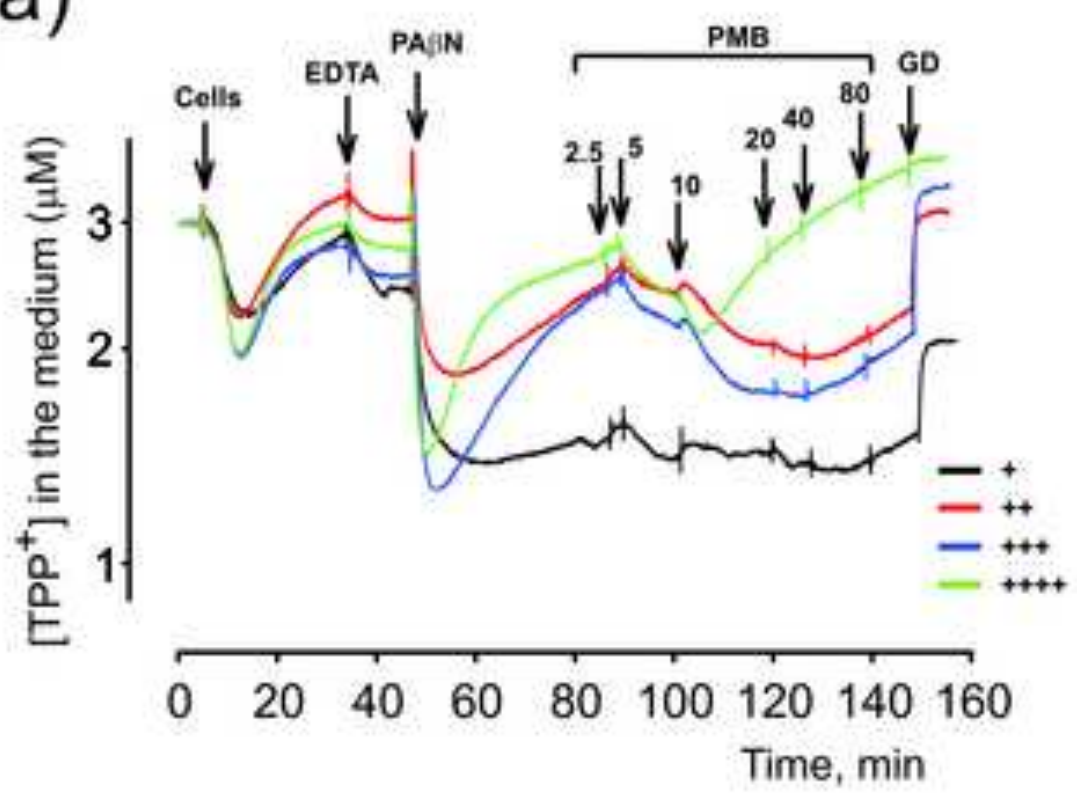

(c)

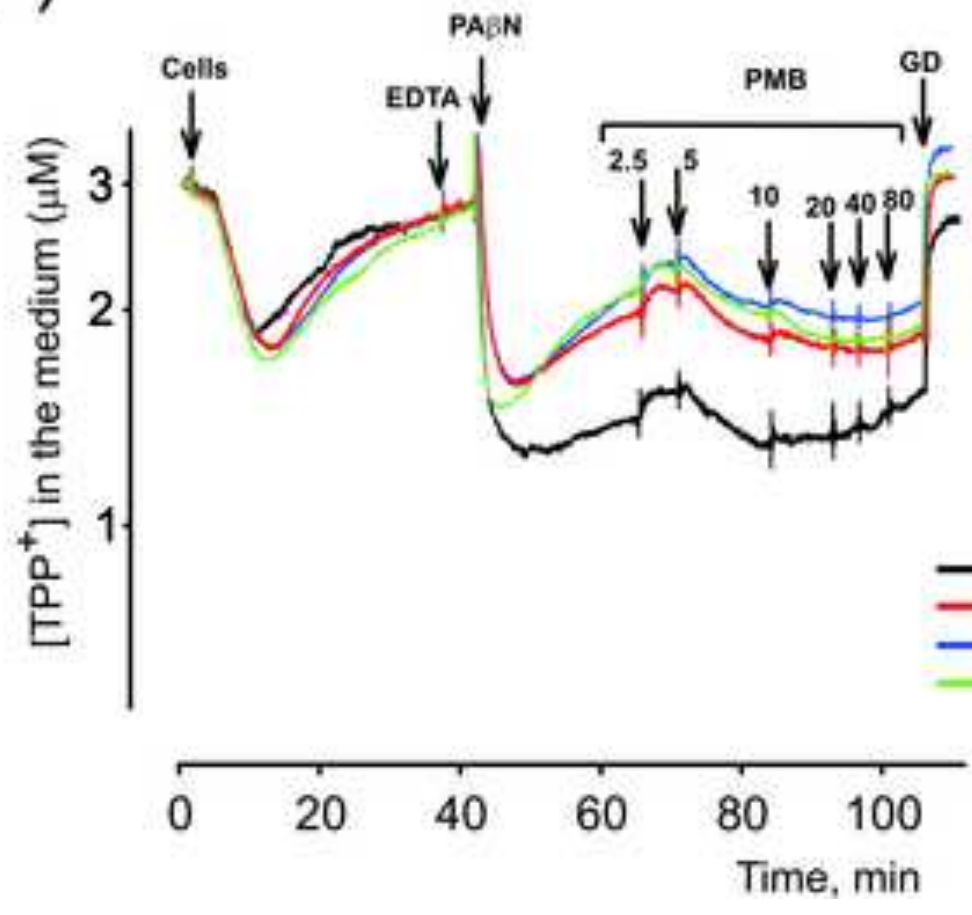

(b)

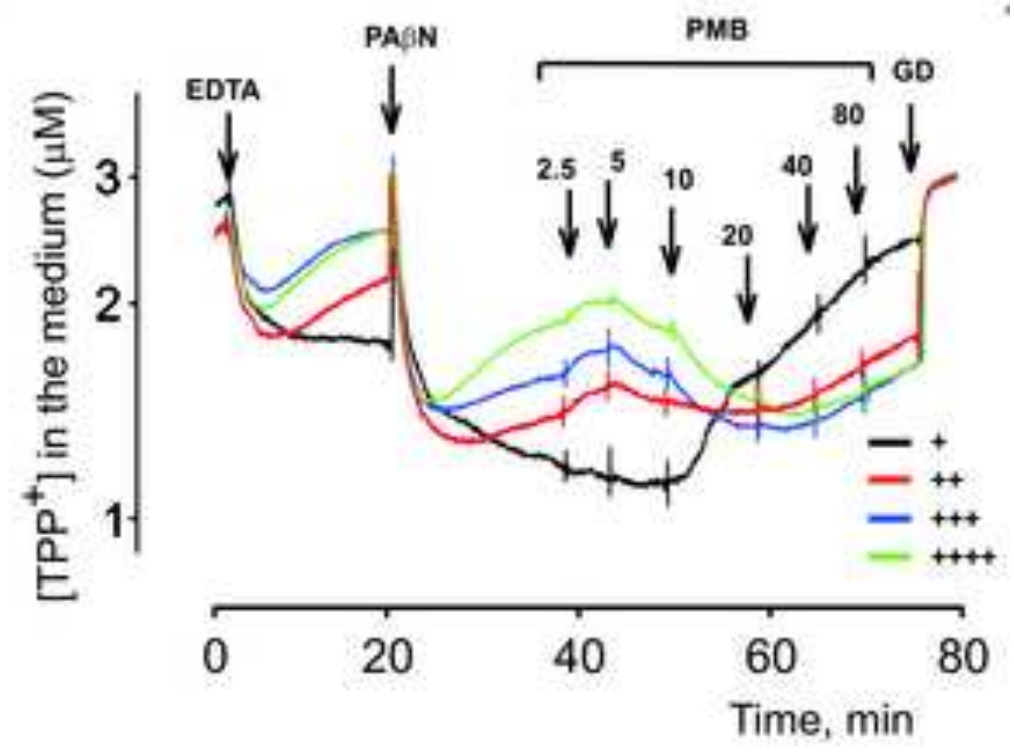

(d)
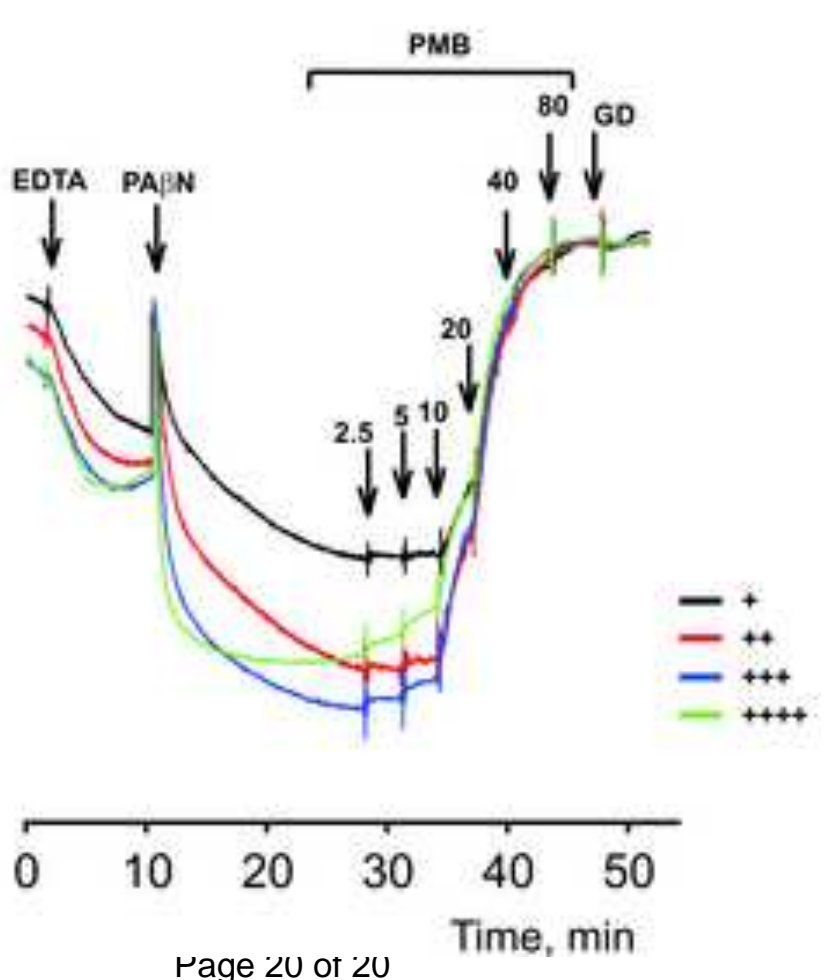